\title{
Variability of Catharanthus roseus based on morphological and anatomical characters, and chlorophyll contents
}

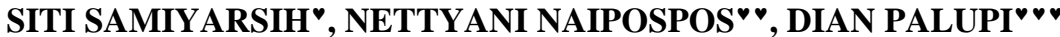 \\ Faculty of Biology, Universitas Jenderal Soedirman. Jl. Dr. Suparno No. 63, Grendeng, Purwokerto, Banyumas 53122, Central Java, Indonesia. Tel.:

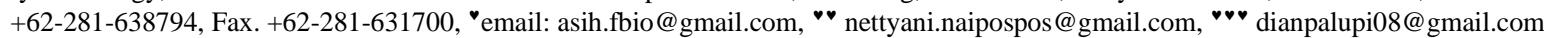

Manuscript received: 9 April 2019. Revision accepted: 18 September 2019.

\begin{abstract}
Samiyarsih S, Naipospos N, Palupi D. 2019. Variability of Catharanthus roseus based on morphological and anatomical characters, and chlorophyll contents. Biodiversitas 20: 2986-2993. Catharanthus roseus (L.) is an important medicinal plant of the family Apocynaceae used to treat many of the diseases. C. roseus also possess good antioxidant potential. The purpose of this research was 1) to determine the variability of $C$. roseus based on the morphological, anatomical characters and chlorophyll contents, 2) to know the differences in morphological, anatomical characteristics and chlorophyll contents of $C$. roseus found in Banyumas Regency. The research used a survey method, with a purposive sampling technique. Preparation of leaf for anatomical analysis was based on paraffin method. The results showed that $C$. roseus in Banyumas Regency were grouped into eight varieties. The morphological characters observed consisted of 21 characters, 8 quantitative characters, and 13 qualitative characters. Most of the quantitative morphological and anatomical characters were significantly diverse $(\mathrm{p}<0.05)$ except for petiole length, corolla number, stomata width and number of trichomata. The eight varieties of $C$. roseus have different chlorophyll a, chlorophyll $\mathrm{b}$, and total chlorophyll contents but their anthocyanin contents were not significantly different.
\end{abstract}

Keywords: Anatomical character, Catharanthus roseus, chlorophyll, morphological character, variability

\section{INTRODUCTION}

Indonesia has a high diversity of medicinal plant's germplasm, one of which is Catharanthus roseus. This high diversity germplasm was obtained through exploration efforts. To be successfully utilized in plant breeding programs, the germplasm must be identified for the important characters, and expected to have a broad diversity. C. roseus is a complex and varied taxon consists of many varieties. This plant has traditionally been used to treat malaria, constipation, diuretics, diabetes mellitus and hypertension. $C$. roseus is commonly grown as an ornamental plant and medicine. This plant contains flavonoids, saponins, tannins, and various kinds of anticancer alkaloids such as vinblastine (VLB), vincristine (VCR) and leurosin (Jaleel et al. 2008; Pandiangan 2012; Nejat et al. 2015).

Catharanthus roseus has a purple, red, pink or white corolla (Plaizier 1981). According to Kumar et al. (2013) and Nejat et al. (2015), there are five variations of flower's color, namely white-yellow, white-red, pink-red, pinkwhite, and red-white. The leaves are widely used as alkaloid-producing medicinal plant materials (Renault et al. 1999). Several studies revealed that the leaves of C. roseus are able to treat various diseases. The existence of the $C$. roseus variety is a very valuable asset as part of germplasm conservation (Adnan et al. 2016).

Morphological dan anatomical characters have an important role in plant taxonomy and identification. The analysis of variance of morphological and anatomical characters revealed significant differences for majority of the tested traits, indicating there was variability among the taro accessions (Pitoyo et al. 2018). Environmental conditions trigger various plant responses including changes in morphology, anatomy, gene expression, cell metabolism and growth and productivity (Anjum et al. 2011). Pantilu et al. (2012) added that the mechanism of adaptation to light intensity is anatomical and morphological changes of leaves to maximize light absorption and photosynthesis efficiency. The physiological responses include increase in leaf area, ratio of chlorophyll $\mathrm{a} / \mathrm{b}$ and anthocyanin pigment while anatomical changes include decreased leaf thickness, cuticle thickness, and trichomata density.

Information on morphological and anatomical characters of $C$. roseus is needed for development and improvement of this medicinal plant species so that its full potential can be optimally utilized. The objective of this research was to determine the variability of $C$. roseus plants in Banyumas Regency based on the morphological, anatomical characters and chlorophyll contents.

\section{MATERIALS AND METHODS}

\section{Study area}

The research employed a survey method, with purposive sampling in the Banyumas District, Central Java Province. Indonesia, including five subdistricts, namely: Sokaraja, Banyumas, Rawalo, Ajibarang, Baturraden, as shown in the following location map (Figure 1). 


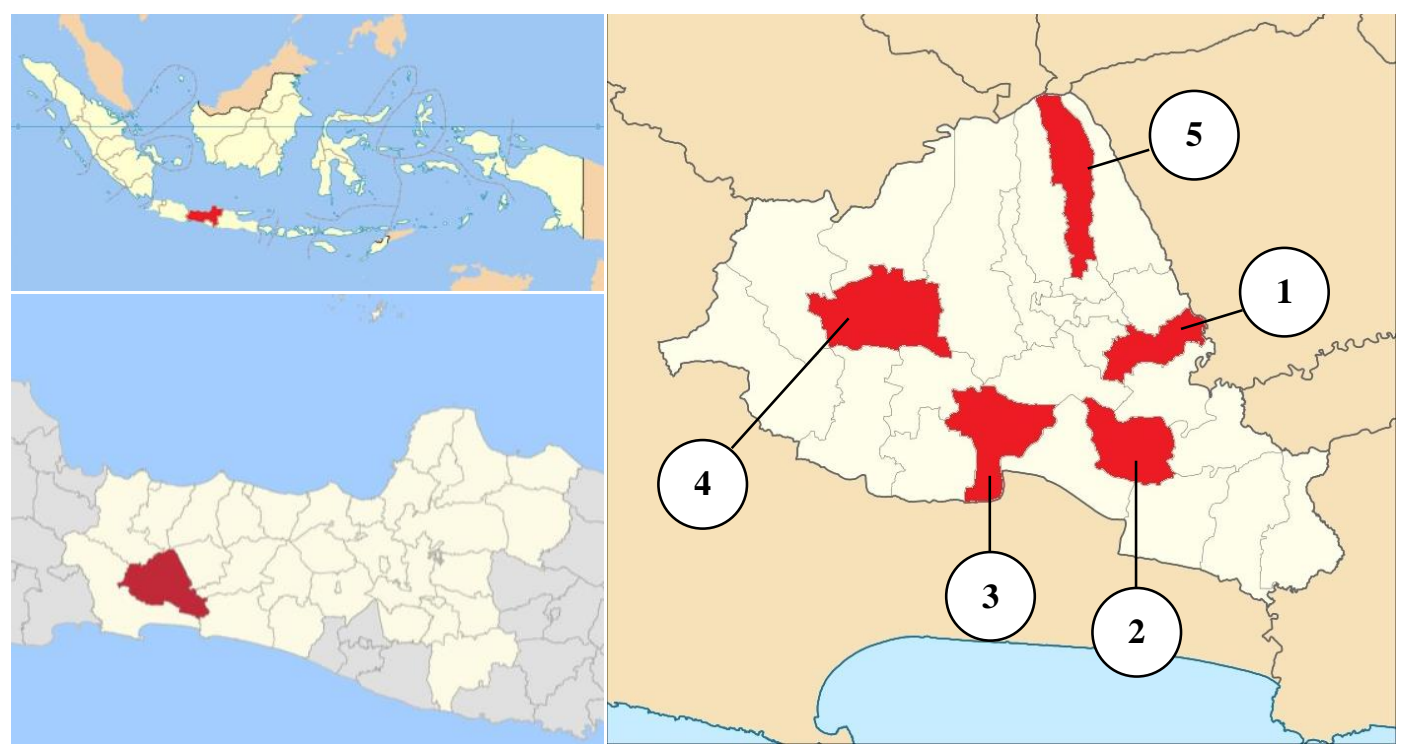

Figure 1. Map of research sampling area in Banyumas District, Central Java, Indonesia. Note: 1. Sokaraja Sub-district, 2. Banyumas Sub-district, 3. Rawalo Sub-district, 4. Ajibarang Sub-district, 5. Baturraden Sub-district

\section{Plant materials}

Catharanthus roseus plants were taken in several areas in Banyumas District including Sub-districts of Sokaraja, Banyumas, Rawalo, Ajibarang and Baturraden (Figure 1). Living plants of eight varieties of $C$. roseus were collected in 24 sites during the field survey. The flowering plants from each variety were collected and then transferred to a polybag and placed in the greenhouse of the Faculty of Biology, Jenderal Soedirman University, for one month. Plants were plantlet under controlled conditions at a temperature of $30^{\circ} / 27^{\circ} \mathrm{C}$ day/night, and relative humidity of $64 \%$. Each plant sample was used for observation of morphological characters, including leaves and flowers. The $5^{\text {th }}$ leaf from the shoot bud was taken to observed the anatomical character of the chlorophyll content. Flower samples were observed for anthocyanin content.

\section{Morphological characters}

Morphological characters measurements were taken on leaves and flowers. Qualitative characters included leaf shape, apex folii, base folii, margo folii, leaf surface color, leaf surface color, leaf surface texture, leaf stalk color, vernatio, inflorescence, flower symmetry, flower location, corolla color, and corolla diameter. Quantitative characters observed were leaf length, leaf width, petiole length, number of corolla, pedicle length, corolla diameter, corolla length, and width. All morphological characters were analyzed descriptively to determine the diversity of $C$. roseus.

\section{Anatomical characters}

The observed anatomical characters included cuticle thickness, epidermis thickness, mesophyll thickness, stomata size, stomata and trichomes density per $1 \mathrm{~mm}^{2}$ area of epidermis of leaves. The $5^{\text {th }}$ leaf from the shoot bud was taken and cut into one $\mathrm{cm}$ pieces, and then was subjected to fixation in FAA solution (FAA: 10\% formalin, 5\% acetic acid, 50\% ethyl alcohol and aquadest 35\%) for 24 hours. Preparation of leaf anatomy was based on the paraffin method, staining was done using safranin $(1 \%)$ in $70 \%$ alcohol. Observation of anatomical characters was performed using a binocular microscope, Olympus CH-20. Measurement of anatomical characters was done using a calibrated ocular micrometer (Hammed et al. 2013; Pitoyo et al. 2018; Samiyarsih et al. 2018).

\section{The measurement of chlorophyll and anthocyanin contents}

Leaf samples were weighed $0.1 \mathrm{mg}$ and extracted with $85 \% 10 \mathrm{~mL}$ acetone solution in a 1: 100 weight ratio. The extract was filtered with a filter paper and analyzed by using a UV Vis spectrophotometer on wavelengths of 644 $\mathrm{nm}$ and $663 \mathrm{~nm}$. Chlorophyll content $\left(\mathrm{mgL}^{-1}\right)$ was determined based on the formula from the method of Gloria and Iswari (2015) and Setiari and Nurchayati (2009) as presented below:

$$
\begin{aligned}
& \text { Chlorophyll a }=1.07(\text { OD 663) }-0.094(\text { OD 644) } \\
& \text { Chlorophyll b = 1.77 (OD 644) }-0.28(\text { OD 663) } \\
& \text { Total Chlorophyll }=0.79(\text { OD 663) + 1,076 (OD 644) }
\end{aligned}
$$

\section{Data analysis}

The observed data of leaf morphological and anatomical characters were analyzed descriptively and used to describe and determine the differences in leaf anatomical characters. Quantitative data including chlorophyll content were subjected to analysis Variance (ANOVA), followed by a Duncan's New Multiple Range Test (DMRT) at a 95\% confidence level to see the variability of the characters and the difference between their means. 


\section{RESULTS AND DISCUSSION}

\section{Morphological characters of $C$. roseus}

Catharanthus roseus plants obtained in this research were classified into eight varieties based on the color of the corolla flowers (Table $1 \mathrm{x}$ ). $C$. roseus is known to be tolerant to abiotic stresses such as drought and salinity, and the plant can survive in a variety of habitats such as sand, bushes, dryland, vineyards, roadsides, and beaches. This plant can grow at altitudes of 0 to 900 meters above sea level. Morphological characters of the eight varieties of $C$. roseus consisted of 21 characters; eight were quantitative characters and 13 were qualitative characters.

Observed qualitative characters included shape of leaf, apex folii, base folii, margo folii, abaxial surface of leaf, leaf surface texture, stalk of leaf, vernatio, inflorescence, flower symmetry, corolla color, does not have high variability (Table 2). C. roseus plants that have different leaf shapes, where varieties $B$ and $E$ have an obovatus leaf shape while the other six varieties have an ovalis leaf shape. In addition, apex folii in variety $\mathrm{D}$ was obtusus while that of seven other varieties was folii mucronatus. Analysis of variance for morphological characters showed a significant difference $(\mathrm{p}<0.05)$ in almost all observed characters of the eight varieties $C$. roseus except for pedicle length and corolla number. Meanwhile, the quantitative characters of leaf length, leaf width, petiole length, corolla diameter, and corolla length varied significantly among the varieties (Table 3 ).
Qualitative characteristics of eight varieties of C. roseus were actinomorphic flower symmetry, axillary flower, compound inflorescence, pinnate leaf, green petiole color, shiny leaf surface, green leaf color, dark green leaf surface, blunt leaf base and oval leaf shape (Figure 2). The qualitative characteristics that distinguished the eight varieties of $C$. roseus were the color of corolla (petala), which is milky white with a red radiating eye, small red center; white with a white eye, yellow center; purple-blue with a white large radiating base, yellow center; pale pink with red radiating eye, red center, pink with a dark pink radiating eye, pink center; pinkish red with a pink radiating eye, yellow center, and whitish pink with a pink radiating eye, yellow center (Figure 3). According to Shaw et al. (2009) and El-Domyati et al. (2012), detection of different varieties was based on the color of the petals and eyes of the flower and the middle color.

Table 1. The classification eight varieties of Catharanthus roseus based on the color of the corolla flowers

\begin{tabular}{lll}
\hline Code & $\begin{array}{c}\text { Name of } \\
\text { varieties }\end{array}$ & Petal color eye color \\
\hline A & Milky white & Red radiating eye with small red center \\
B & White & White eye with yellow center \\
C & Purple blue & White large radiating base with yellow center \\
D & Pale pink & White eye with yellow center \\
E & Pink & Dark pink radiating eye with pink center \\
F & Pinkish red & Pink radiating eye with yellow center \\
G & Pinkish red & Red radiating eye with yellow center \\
H & Whitish pink & Pink radiating eye with yellow center \\
\hline
\end{tabular}

Table 2. The qualitative morphological characters of eight varieties of Catharanthus roseus

\begin{tabular}{|c|c|c|c|c|c|c|c|c|c|c|c|}
\hline Var. & $\begin{array}{l}\text { Leaf } \\
\text { shape }\end{array}$ & Apex folii & $\begin{array}{l}\text { Base } \\
\text { folii }\end{array}$ & $\begin{array}{c}\text { Margo } \\
\text { folii }\end{array}$ & $\begin{array}{c}\text { Leaf } \\
\text { abaxial } \\
\text { surface }\end{array}$ & $\begin{array}{c}\text { Leaf } \\
\text { surface } \\
\text { texture }\end{array}$ & Leaf stalk & Vernatio & Inflorescence & $\begin{array}{c}\text { Flower } \\
\text { symmetry }\end{array}$ & $\begin{array}{l}\text { Flower } \\
\text { location }\end{array}$ \\
\hline A & & & & & & & & & & & \\
\hline B & & & & & & & & & & & \\
\hline $\mathrm{C}$ & & & & & & & & & & & \\
\hline D & & & & & & & & & & & \\
\hline $\mathrm{E}$ & & & Obtu & & & & & & & & \\
\hline $\mathrm{F}$ & & & & & & & & & & & \\
\hline G & & & & & & & & & & & \\
\hline $\mathrm{H}$ & Ovalis & Mucronatus & Obtusus & Integer & Dark-green & Shiny & Light green & Pinnate & Compound & Actinomorph & Axilaris \\
\hline
\end{tabular}

Note: qualitative morphological characters of leaves and flowers of C. roseus. Note: Varieties of A-H were distinguished based on the color of the corolla as indicated in Table 1

Table 3. The average of quantitative characters of the eight varieties of Catharanthus roseus

\begin{tabular}{|c|c|c|c|c|c|c|}
\hline Varieties & $\begin{array}{l}\text { Leaf length } \\
(\mathrm{cm})\end{array}$ & $\begin{array}{l}\text { Leaf width } \\
\text { (cm) }\end{array}$ & $\begin{array}{l}\text { Petiole length } \\
(\mathrm{cm})\end{array}$ & $\begin{array}{l}\text { Pedicle length } \\
(\mathrm{cm})\end{array}$ & $\begin{array}{c}\text { Corolla } \\
\text { diameter }(\mathrm{cm})\end{array}$ & $\begin{array}{l}\text { Corolla length } \\
(\mathrm{cm})\end{array}$ \\
\hline $\mathrm{A}$ & $5.76 \pm 1.60 \mathrm{~b}$ & $2.64 \pm 0.58 b$ & $0.72 \pm 0.15 b$ & $2.56 \pm 0.05 \mathrm{a}$ & $4.54 \pm 0.05 b$ & $2.24 \pm 0.05 b$ \\
\hline B & $4.92 \pm 1.50 \mathrm{a}$ & $1.84 \pm 0.41 \mathrm{c}$ & $1.76 \pm 0.10 \mathrm{c}$ & $2.66 \pm 0.05 a$ & $5.16 \pm 0.05 c$ & $2.56 \pm 0.05 b$ \\
\hline $\mathrm{C}$ & $6.02 \pm 1.61 b$ & $2.70 \pm 0.60 \mathrm{~b}$ & $0.56 \pm 0.16 \mathrm{a}$ & $2.34 \pm 0.05 \mathrm{a}$ & $3.82 \pm 0.07 \mathrm{a}$ & $1.98 \pm 0.07 \mathrm{a}$ \\
\hline $\mathrm{D}$ & $5.58 \pm 1.51 b$ & $2.16 \pm 0.74 d$ & $0.48 \pm 0.13 \mathrm{a}$ & $2.32 \pm 0.04 \mathrm{a}$ & $4.24 \pm 0.05 b$ & $2.06 \pm 0.05 b$ \\
\hline $\mathrm{E}$ & $5.70 \pm 1.23 b$ & $2.36 \pm 0.47 b$ & $0.70 \pm 0.20 \mathrm{~b}$ & $2.44 \pm 0.05 \mathrm{a}$ & $4.66 \pm 0.05 b$ & $2.28 \pm 0.04 b$ \\
\hline $\mathrm{F}$ & $4.78 \pm 1.11 \mathrm{a}$ & $1.70 \pm 0.42 \mathrm{c}$ & $0.74 \pm 0.16 b$ & $3.54 \pm 0.05 b$ & $4.14 \pm 0.05 b$ & $2.10 \pm 0.06 \mathrm{~b}$ \\
\hline $\mathrm{H}$ & $4.44 \pm 1.03 \mathrm{c}$ & $1.34 \pm 0.33 \mathrm{a}$ & $0.70 \pm 0.09 \mathrm{~b}$ & $2.44 \pm 0.08 \mathrm{a}$ & $4.26 \pm 0.05 b$ & $2.04 \pm 0.05 b$ \\
\hline
\end{tabular}

Note: Numbers followed by the same letters in the same column are not significantly different (p>0.05). Note: Varieties of A-H were distinguished based on the color of the corolla as indicated in Table 1 


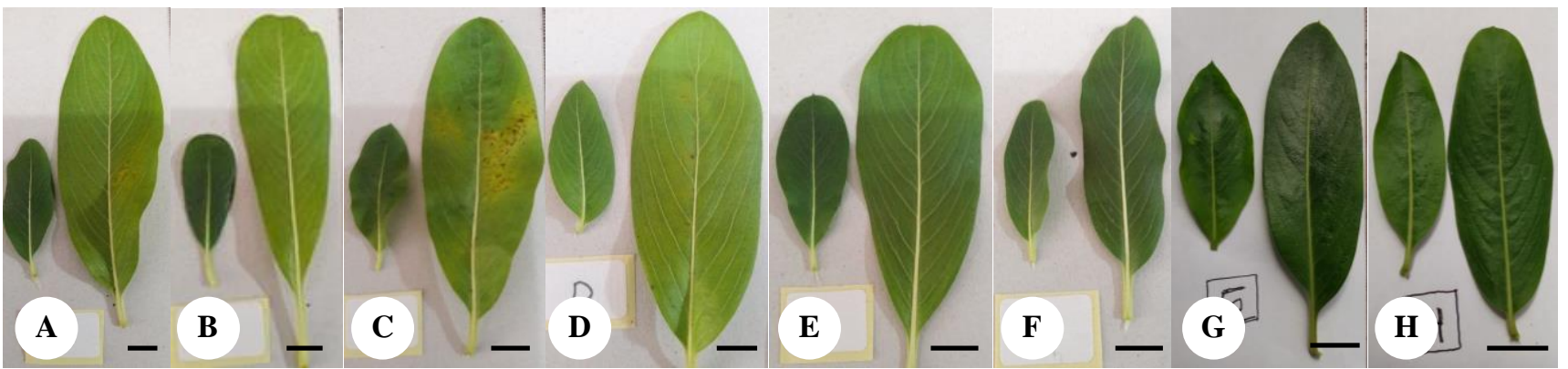

Figure 2. Morphology of leaves of eight varieties of Catharanthus roseus (L.). Bar $=1 \mathrm{~cm}$. Note: Varieties of A-H were distinguished based on the color of the corolla as indicated in Table 1

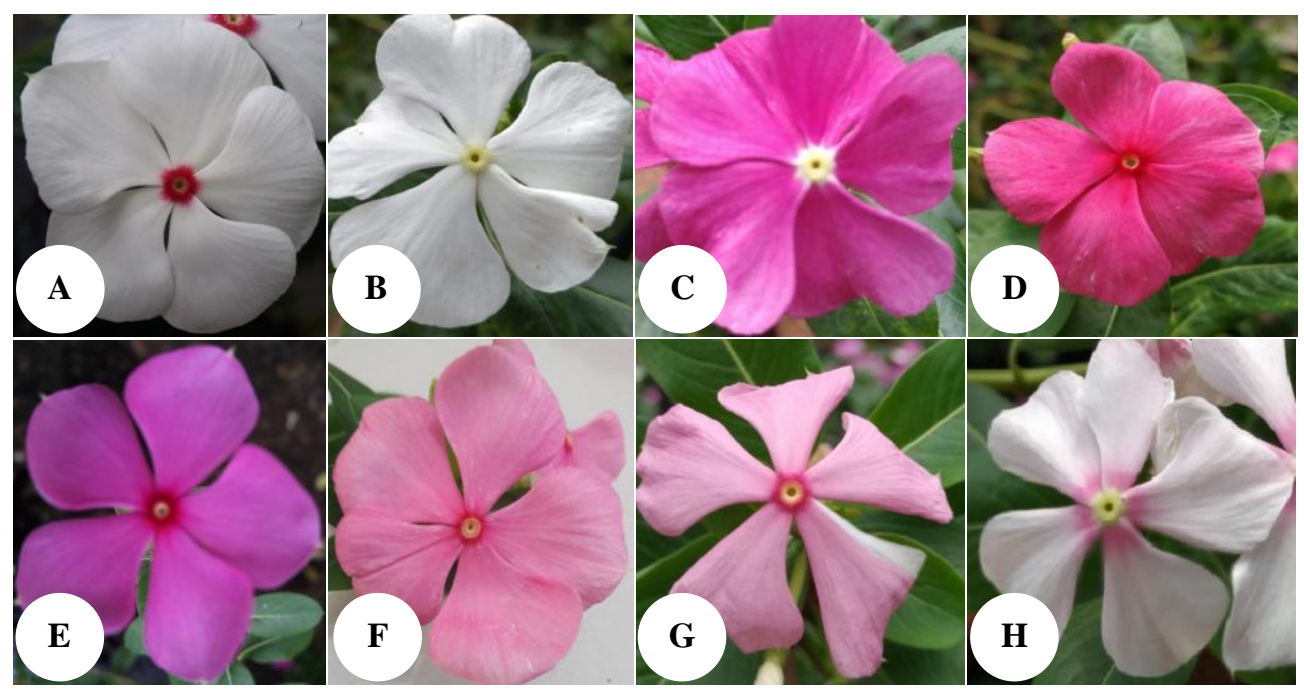

Figure 3. Photographs of the color flowers the eight varieties of Catharanthus roseus. Note: Varieties of A-H were distinguished based on the color of the corolla as indicated in Table 1

Table 4. The average of anatomical character of eight varieties of Catharanthus roseus

\begin{tabular}{cccccc}
\hline Varieties & $\begin{array}{c}\text { Cuticle thickness } \\
\text { adaxial }(\boldsymbol{\mu m})\end{array}$ & $\begin{array}{c}\text { Cuticle thickness } \\
\text { abaxial }(\boldsymbol{\mu m})\end{array}$ & $\begin{array}{c}\text { Epidermis thickness } \\
\text { adaxial }(\boldsymbol{\mu m})\end{array}$ & $\begin{array}{c}\text { Epidermis thickness } \\
\text { abaxial }(\boldsymbol{\mu m})\end{array}$ & $\begin{array}{c}\text { Mesophyll } \\
\text { thickness }(\boldsymbol{\mu m})\end{array}$ \\
\hline $\mathrm{A}$ & $4.75 \pm 0.37 \mathrm{ab}$ & $3.25 \pm 0.34 \mathrm{a}$ & $13.40 \pm 1.07 \mathrm{a}$ & $10.75 \pm 0.68 \mathrm{a}$ & $169.5 \pm 5.86 \mathrm{bcd}$ \\
$\mathrm{B}$ & $5.25 \pm 0.37 \mathrm{ab}$ & $3.00 \pm 0.34 \mathrm{a}$ & $22.50 \pm 1.07 \mathrm{~d}$ & $16.70 \pm 0.68 \mathrm{c}$ & $170.0 \pm 5.86 \mathrm{bcd}$ \\
$\mathrm{C}$ & $5.70 \pm 0.37 \mathrm{a}$ & $2.85 \pm 0.34 \mathrm{a}$ & $18.75 \pm 1.07 \mathrm{bc}$ & $12.50 \pm 0.68 \mathrm{ab}$ & $149.0 \pm 5.86 \mathrm{a}$ \\
$\mathrm{D}$ & $4.25 \pm 0.37 \mathrm{~b}$ & $1.75 \pm 0.34 \mathrm{~b}$ & $17.50 \pm 1.07 \mathrm{~b}$ & $11.25 \pm 0.68 \mathrm{a}$ & $176.5 \pm 5.86 \mathrm{bcd}$ \\
$\mathrm{E}$ & $2.75 \pm 0.37 \mathrm{c}$ & $1.75 \pm 0.34 \mathrm{~b}$ & $21.50 \pm 1.07 \mathrm{~cd}$ & $14.00 \pm 0.68 \mathrm{~b}$ & $185.5 \pm 5.86 \mathrm{~d}$ \\
$\mathrm{~F}$ & $3.00 \pm 0.37 \mathrm{c}$ & $1.25 \pm 0.34 \mathrm{~b}$ & $24.00 \pm 1.07 \mathrm{~cd}$ & $17.50 \pm 0.68 \mathrm{c}$ & $181.5 \pm 5.86 \mathrm{~cd}$ \\
$\mathrm{G}$ & $2.25 \pm 0.37 \mathrm{c}$ & $2.25 \pm 0.34 \mathrm{ab}$ & $24.00 \pm 1.07 \mathrm{~d}$ & $16.00 \pm 0.68 \mathrm{c}$ & $165.5 \pm 5.86 \mathrm{abc}$ \\
$\mathrm{H}$ & $2.00 \pm 0.37 \mathrm{c}$ & $1.50 \pm 0.34 \mathrm{~b}$ & $24.00 \pm 1.07 \mathrm{~d}$ & $17.00 \pm 0.68 \mathrm{c}$ & $162.5 \pm 5.86 \mathrm{ab}$ \\
\hline
\end{tabular}

Note: Numbers followed by the same letters in the same column are not different significant at the level of $\mathrm{p}<0.05$. Varieties of A-H were distinguished based on the color of the corolla as indicated in Table 1

Table 5. The average of length, width, stomata and trichomes density of eight varieties Catharanthus roseus

\begin{tabular}{|c|c|c|c|c|c|c|}
\hline Varieties & $\begin{array}{c}\text { Length of } \\
\text { adaxial } \\
\text { stomata }(\boldsymbol{\mu m})\end{array}$ & $\begin{array}{c}\text { Length of } \\
\text { abaxial stomata } \\
(\mu \mathrm{m})\end{array}$ & $\begin{array}{l}\text { Width of adaxial } \\
\text { stomata }(\mu \mathrm{m})\end{array}$ & $\begin{array}{c}\text { Width of } \\
\text { abaxial } \\
\text { stomata }(\mu \mathrm{m})\end{array}$ & $\begin{array}{c}\text { Density of } \\
\text { stomata }\left(\mathrm{mm}^{2}\right)\end{array}$ & $\begin{array}{c}\text { Density of } \\
\text { trichomes } \\
\left(\mathrm{mm}^{2}\right)\end{array}$ \\
\hline A & $23.60 \pm 0.54 a$ & $19.10 \pm 0.89 b$ & $7.10 \pm 0.33 a$ & $7.95 \pm 0.29 b$ & $17.00 \pm 0.14 b$ & $3.80 \pm 0.28 b$ \\
\hline B & $21.75 \pm 0.54 b$ & $20.25 \pm 0.89 b$ & $6.70 \pm 0.33 \mathrm{ab}$ & $7.85 \pm 0.29 b$ & $16.40 \pm 0.14 b$ & $4.60 \pm 0.28 \mathrm{a}$ \\
\hline $\mathrm{C}$ & $17.25 \pm 0.54 \mathrm{c}$ & $17.40 \pm 0.89 b$ & $5.65 \pm 0.33 \mathrm{~cd}$ & $7.65 \pm 0.29 b$ & $14.40 \pm 0.14 b$ & $3.60 \pm 0.28 b$ \\
\hline $\mathrm{D}$ & $14.30 \pm 0.54 \mathrm{~d}$ & $16.75 \pm 0.89 a$ & $6.60 \pm 0.33 \mathrm{abc}$ & $6.10 \pm 0.29 a$ & $18.00 \pm 0.14 \mathrm{a}$ & $3.80 \pm 0.28 b$ \\
\hline $\mathrm{E}$ & $16.50 \pm 0.54 c$ & $17.90 \pm 0.89 a$ & $7.00 \pm 0.33 \mathrm{a}$ & $6.35 \pm 0.29 a$ & $15.00 \pm 0.14 \mathrm{a}$ & $4.80 \pm 0.28 \mathrm{a}$ \\
\hline $\mathrm{F}$ & $23.50 \pm 0.54 a$ & $20.30 \pm 0.89 b$ & $5.55 \pm 0.33 \mathrm{~d}$ & $8.10 \pm 0.29 c$ & $13.80 \pm 0.14 b$ & $4.60 \pm 0.28 a$ \\
\hline $\mathrm{H}$ & $16.40 \pm 0.54 c$ & $19.10 \pm 0.89 b c$ & $6.30 \pm 0.33 \mathrm{abcd}$ & $8.40 \pm 0.29 c$ & $16.80 \pm 0.14 b c$ & $3.60 \pm 0.28 b$ \\
\hline
\end{tabular}

Note: Numbers followed by the same letters in the same column are not different significant at the level of $\mathrm{p}<0.05$. Varieties of A-H 


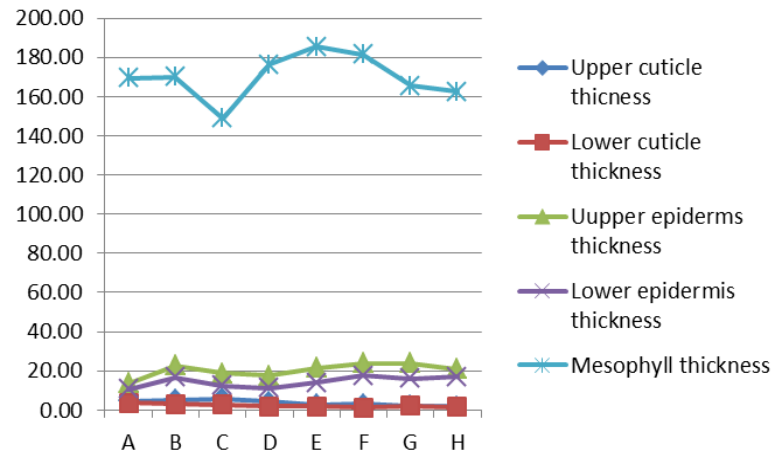

Figure 4. Thickness of cuticles, epidermis and mesophyll leaves of eight $C$. roseus varieties

In general, the results showed that $C$. roseus had low variability in qualitative characters such as leaf shape, apex folii, base folii, surface of leaf, vernatio, inflorescence, and symmetry of flower and location of flower. Morphological characters such as plant height, leaf length, leaf width, petiole length, flower diameter, and corolla length were highly variable. This shows that morphological characters can be used to distinguish variability of $C$. roseus. Leaf characters are often ignored by taxonomists when identifying and classifying plants because of their high phenotypic plasticity. Leaf characters, especially venation patterns, are genetically improved so that they can be used as taxonomic tools (Masungsong et al. 2019). Morphological characters are still routinely used for preliminary evaluation because they are fast, simple, cheap and can be used as a general approach to assessing plant genetic diversity (Jingura and Kamusoko 2015). Pitoyo et al. (2018) reported that taro accessions showed high variability in morphological characters. Morphological characters, therefore, can be used to distinguish the variability of varieties.

The anatomical character of Catharanthus roseus leaves

Anatomical character is one approach used to help solving taxonomic problems that are morphologically difficult to separate or still doubtful. Custódio et al. (2013) stated that the commonly used anatomical characters were epidermal thickness, mesophyll thickness, cuticle thickness, leaf mesophyll character (palisade and sponge), stomata density, stomata length, and width.

The analysis results showed that the eight observed varieties of $C$. roseus varied greatly in characters such as cuticle thickness, epidermis thickness, mesophyll thickness, stomata length and density of the observed varieties (Tables 2-3; Figures 4-5; Figures 6-7). Analysis of variance showed the eight $C$. roseus varieties were significantly different $(\mathrm{p}<0.05)$ for all observed anatomical characters, except for stomata width and trichome density per $1 \mathrm{~mm}^{2}$ of leaf area. The cuticle of the leaves functions as a response to changes in environmental factors that are unfavorable to plants, and the thickness of the cuticle plays a role in reducing the rate of transpiration in the leaves (Tanzerina et al. 2013). The thickness of the cuticle layer is influenced by the presence of cutin compounds which are

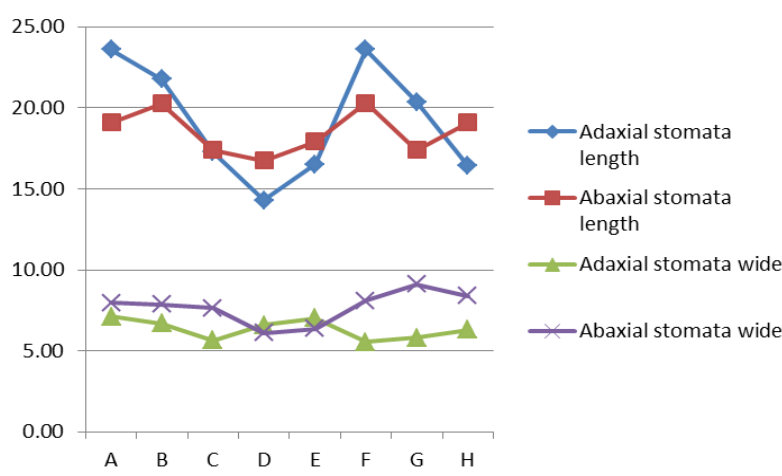

Figure 5. The length and width of the stomata of the leaves of eight $C$. roseus varieties

able to prevent the evaporation of water molecules from the leaves (Ali et al. 2009). Pitoyo et al. (2018) reported significant differences for the majority the anatomical characters of taro indicating a high variability among the taro accessions.

Mesophyll is located between the two epidermal layers, differentiated into palisade parenchymal tissue and spongy parenchyma. The palisade parenchyma is elongated and tightly arranged. The spongy parenchyma consists of cells with a lot of space between cells (Figure 6). The observations results showed that the eight $C$. roseus varieties significantly differed in the above quantitative anatomical characters. Mesophyll thickness of $C$. roseus leaves ranged between $149.00-185.50 \mu \mathrm{m}$. According to Salisbury and Ross (1995), palisade cells will elongate, thicken or form additional layers of palisade when the plants receive high light intensity. Pantilu et al. (2012) added that plants that receive high light intensity produce smaller leaf, thicker and compact palisade, and small cell space. The thickness of leaf mesophyll is also determined by marginal initial cell division and submarginal initials.

The ANOVA results of showed that the eight varieties were significantly different $(p<0.05)$ in their stomata density. The highest stomata density (stomata per $1 \mathrm{~mm}^{2}$ of leaf area) was observed in $C$. roseus with a Pale pink corolla color, red radiating eye with red center (D), while the lowest stomata density was found in C. roseus with a Pinkish red corolla color, pink radiating eye with yellow center (F) (13.6 stomata per $1 \mathrm{~mm}^{2}$ of leaf area). The surface of the abaxial epidermis has a higher stomata density compared to the surface of the adaxial epidermis. The length and width of the stomata were also significantly different among the eight varieties $(p<0.05)$. The longer and wider stomata will result in a high transpiration rate because more water molecules are released by the leaves, which will increase the absorption of nutrients from the soil. The absorbed nutrients are then used for photosynthesis, which causes an increase in the rate of photosynthesis, and hence, affects plant growth and development. Hameed et al. (2013) stated that the surface of the abaxial epidermis has a higher stomata density than the surface of the adaxial epidermis. Stomata density and size affect the transpiration process or the efficient use of $\mathrm{O}_{2}$ and $\mathrm{CO}_{2}$ in plants. 


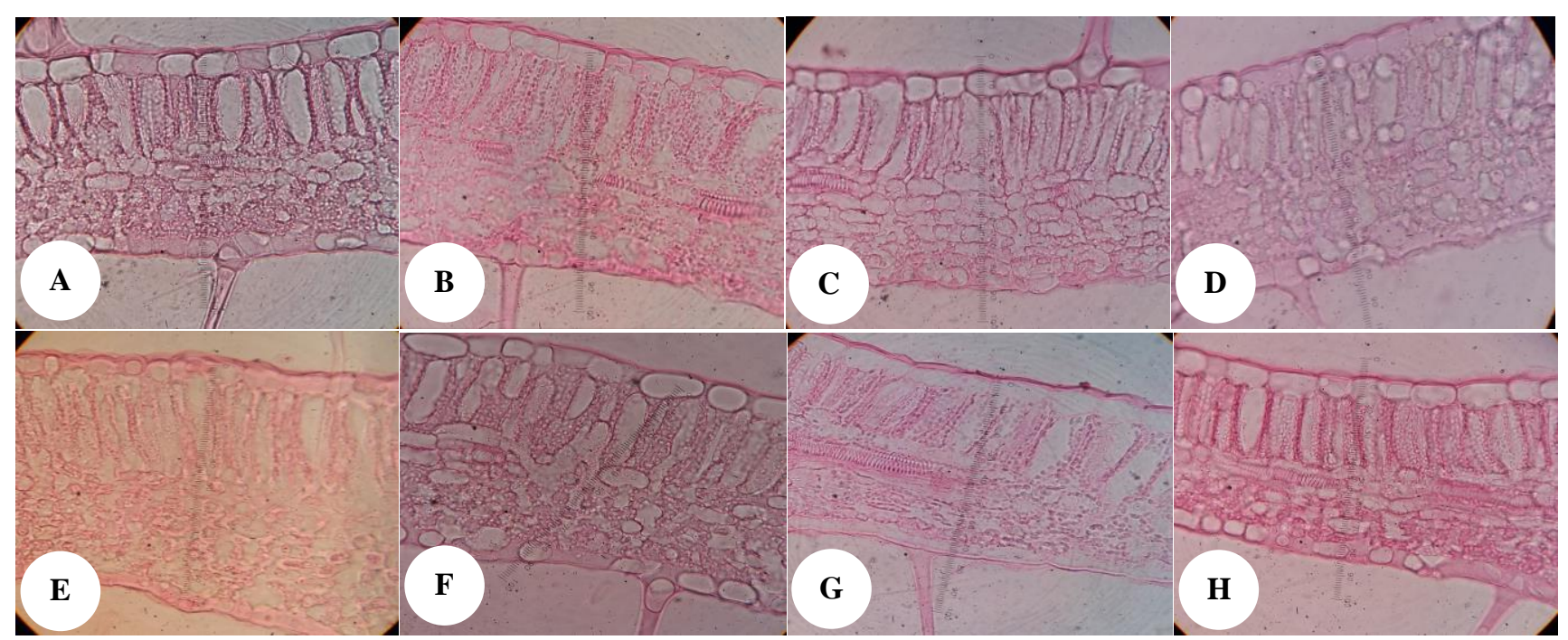

Figure 6. Cross-section of leaf eight varieties Catharanthus roseus, magnification of 400x. Note: Varieties of A-H were distinguished based on the color of the corolla as indicated in Table 1

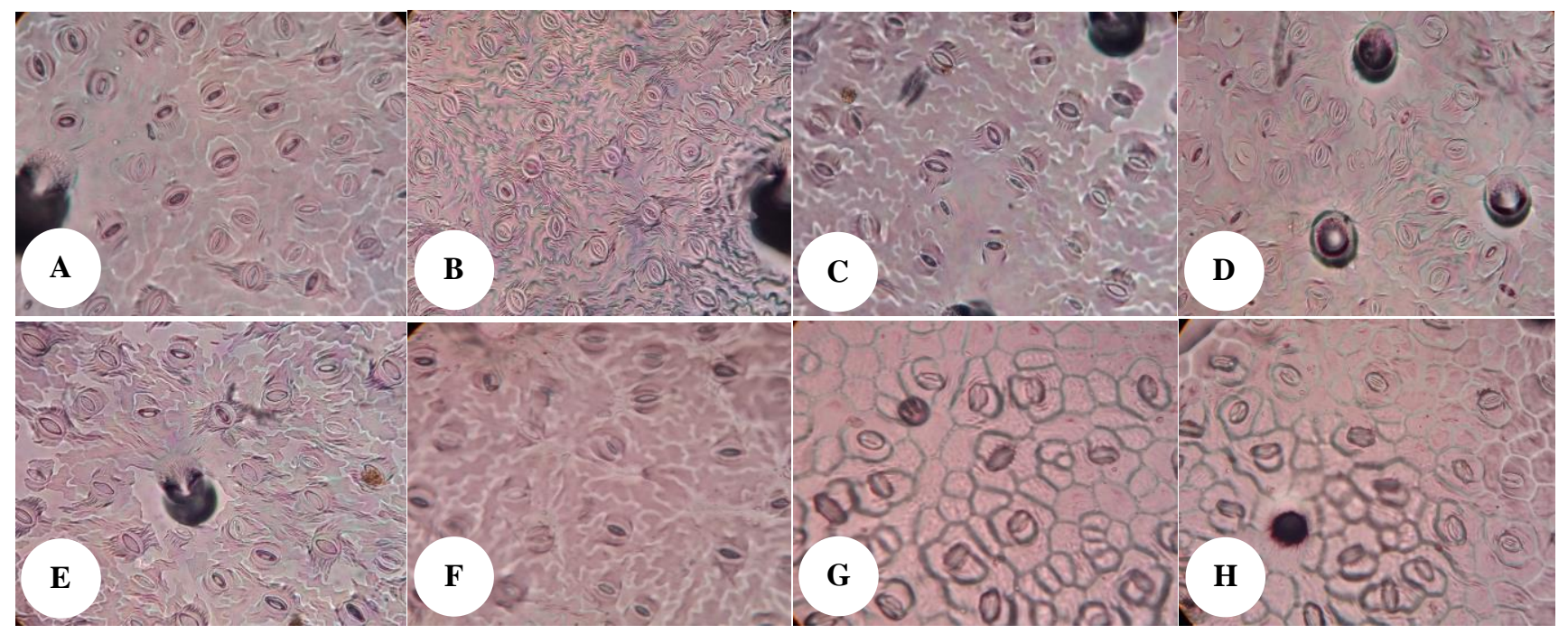

Figure 7. The stomata dan trichomes of eight Catharanthus roseus varieties, magnification of 400x. Note: Varieties of A-H were distinguished based on the color of the corolla as indicated in Table 1

Table 6. Average chlorophyll a, b, total chlorophyll and anthocyanin contents of eight Catharanthus roseu. varieties.

\begin{tabular}{|c|c|c|c|c|}
\hline Variety & $\begin{array}{c}\text { Chlorophyll a } \\
\left(\mathrm{mgL}^{-1}\right)\end{array}$ & $\begin{array}{c}\text { Chlorophyll b } \\
\left(\mathrm{mgL}^{-1}\right)\end{array}$ & $\begin{array}{c}\text { Total chlorophyll } \\
\left(\mathrm{mgL}^{-1}\right)\end{array}$ & $\begin{array}{c}\text { Anthocyanin } \\
\left(\mathrm{mgL}^{-1}\right)\end{array}$ \\
\hline A & $8.99 \pm 0.21 \mathrm{~cd}$ & $3.81 \pm 0.11 \mathrm{~cd}$ & $0.79 \pm 0.49 \mathrm{~b}$ & $0.19 \pm 0.018$ \\
\hline B & $9.80 \pm 0.21 \mathrm{~cd}$ & $3.88 \pm 0.11 \mathrm{~cd}$ & $0.88 \pm 0.49 b c$ & $0.20 \pm 0.018$ \\
\hline $\mathrm{C}$ & $12.24 \pm 0.21 \mathrm{e}$ & $4.82 \pm 0.11 \mathrm{~d}$ & $0.47 \pm 0.49 a$ & $0.18 \pm 0.018$ \\
\hline $\mathrm{D}$ & $6.41 \pm 0.21 \mathrm{ab}$ & $3.30 \pm 0.11 \mathrm{ab}$ & $0.89 \pm 0.49 b c$ & $0.20 \pm 0.018$ \\
\hline $\mathrm{E}$ & $8.66 \pm 0.21 b c$ & $3.60 \pm 0.11 b c$ & $1.11 \pm 0.49 \mathrm{~d}$ & $0.22 \pm 0.018$ \\
\hline $\mathrm{F}$ & $7.96 \pm 0.21 \mathrm{a}$ & $3.10 \pm 0.11 \mathrm{a}$ & $0.97 \pm 0.49 \mathrm{~cd}$ & $0.22 \pm 0.018$ \\
\hline G & $8.05 \pm 0.21 \mathrm{~cd}$ & $3.64 \pm 0.11 \mathrm{~cd}$ & $0.78 \pm 0.49 b$ & $0.17 \pm 0.018$ \\
\hline $\mathrm{H}$ & $11.16 \pm 0.21 \mathrm{~d}$ & $3.98 \pm 0.11 \mathrm{~d}$ & $0.74 \pm 0.49 b c$ & $0.22 \pm 0.018$ \\
\hline
\end{tabular}

Note: Numbers followed by the same letters in the same column are not significantly different at the level of $\mathrm{p}<0.05$. Columns that are not followed by letters indicate that treatment had no significant effect. Varieties of A-H were distinguished based on the color of the corolla as indicated in Table $1 \mathrm{x}$ 


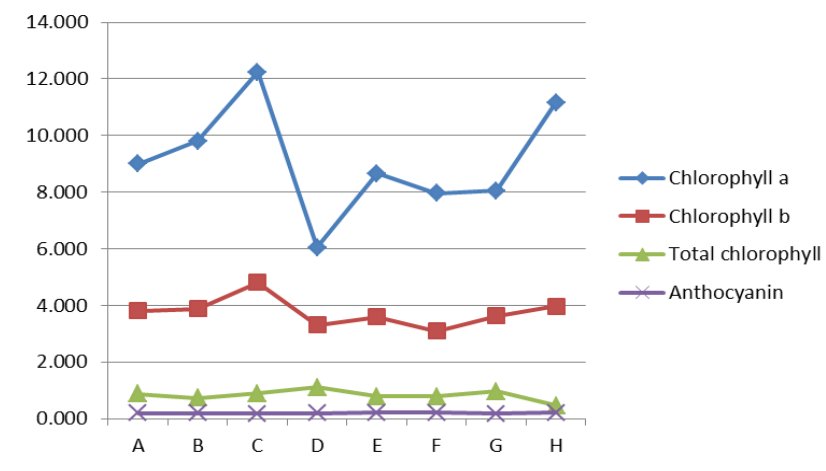

Figure 8. The contents of chlorophyll a, b and total chlorophyll, and anthocyanin of eight $C$. roseus varieties

Plants have the ability to respond to their needs, especially during their life cycle, if environmental factors are not supportive. This response can be in morphological, physiological or anatomical forms. Maghsoudi and Moud (2008) stated that light intensity, air humidity, and $\mathrm{CO}_{2}$ concentration are environmental factors that influence changes in stomata size. Stomata have an important role in respiration, photosynthesis and transpiration processes in plants. Opening of stomata on the leaf surface is to release air in the form of steam into the atmosphere (Saadu et al. 2009). According to Haryanti (2010) stomata have a mechanism of adaptation to changes in groundwater content, which is affected by the capacity of the soil in water storage. Adams et al. (2011) stated that the most beneficial adaptation of plants in responding to the effect of environmental factors is to maintain the rate of transpiration by reducing the density and size of stomata.

\section{The chlorophyll and anthocyanin contents}

ANOVA results showed that chlorophyll and anthocyanin were not significantly different $(\mathrm{p}<0.05)$ among the eight $C$. roseus varieties. Chlorophyll that is synthesized in leaves is different in number for each type of plant depending on environmental and genetic factors. One of the internal factors that affect the rate of photosynthesis is the leaf chlorophyll content. The higher the chlorophyll content, the more efficient it will be in capturing sunlight energy for photosynthesis. The results of measurement of chlorophyll and anthocyanin content in eight varieties of $C$. roseus are presented in Table 6 and Figure 8 .

Based on Table 6 and Figure 8, the highest chlorophyll $\mathrm{a}$ and chlorophyll $\mathrm{b}$ contents in the leaves were observed in C. roseus verities with purple blue (C), respectively, 12.24 $\mathrm{mgL}^{-1}$ and $4.82 \mathrm{mgL}^{-1}$. The chlorophyll a and chlorophyll $\mathrm{b}$ contents in plants affect growth and development processes. The higher the chlorophyll a and chlorophyll $b$ contents, the higher the rate of photosynthesis will be, which causes a more optimal absorption of nutrients from the soil, which will stimulate plant growth and development. There was a linear relationship between leaf mesophyll thickness and the total chlorophyll content, where the thicker the mesophyll, the higher the total chlorophyll content. Variety E (pink) has the thickness mesophyll $(185.5 \mu \mathrm{m})$ and the highest total chlorophyll content (1.11 $\mathrm{mgL}^{-1}$ ) According to Taiz and Zieger (1998), chlorophyll $\mathrm{a}$ and chlorophyll $\mathrm{b}$ are very good at absorbing the red spectrum. This red spectrum with a wavelength of 630 - $675 \mathrm{~nm}$ will later be used to produce energy in photosystem I and photosystem II. The energy produced will be used for the growth process. Zen et al. (2016) reported that photosynthesis occurs perfectly because there are thick palisades that contain lots of chlorophyll, so photosynthesis rates increase, plant growth increases and productivity also increases. Factors that influence chlorophyll synthesis include light, water, temperature, sugar or carbohydrates, genetic factors and elements such as nitrogen, magnesium, iron, manganese, $\mathrm{Cu}, \mathrm{Zn}$, sulfur, and oxygen.

The study results showed no relationship between anthocyanin content and corolla color in the eight varieties. Varieties E (Pink), F (Pinkish red) and H (Whitish pink) have the highest anthocyanin content $\left(0.22 \mathrm{mgL}^{-1}\right)$ and the anthocyanin content of variety $\mathrm{G}$ (Pinkish red) was 0.17 $\mathrm{mgL}^{-1}$. This shows that the $\mathrm{G}$ (Pinkish red) variety with sharp corolla color has the lowest anthocyanin content, while the $\mathrm{H}$ (Whitish pink) variety with pale corolla has the highest anthocyanin content. The difference in anthocyanin content can also be caused by differences in their ability to synthesize anthocyanin. Mlodzinska (2009) stated that the biosynthetic ability of each plant in producing color pigments is not the same, resulting in different color of the plant organs. Hasidah reported that the low anthocyanin level in plants was due to the inhibition of anthocyanin synthesis activity by chlorophyll synthesis.

To conclude, 21 morphological characters (8 quantitative and 13 qualitative characters) were observed in eight varieties of Catharanthus roseus in Banyumas Regency. Almost all quantitative morphological and anatomical characters were significantly diverse $(p<0.05)$ among the eight varieties, except for petiole length, corolla number, stomata width and trichomata number. The eight varieties of $C$. roseus have different contents of chlorophyll $\mathrm{a}$, chlorophyll b, and total chlorophyll contents, but their anthocyanin content was not significantly different.

\section{ACKNOWLEDGEMENTS}

We are grateful to the Institute for Research and Community Services (LPPM) of University Jenderal Soedirman for supporting the research fund through Competency Research Scheme No. DIPA042.06.1.401516/2018. We extend our thanks to Supriyono and Nur Fitrianto for their assistance in carrying out this research.

\section{REFERENCES}

Adams TD, Hunt L, Franks PJ, Beerling DJ, Gray JE. 2012. Genetic manipulation of stomatal density influences stomatal size, plant 
growth and tolerance to restricted water supply across a growth carbon dioxide gradient. Phil Trans R Soc B 367: 547-555.

Adnan, Kurnia N, Saenab S. 2016. Utilization of Catharanthus roseus as senior high school and biology science learning resource. J Bionat 17 (2): 97-101. [Indonesian]

Ali I, Abbas SQ, Hameed M, Naz S, Zafar S, Kanwal S. 2009. Leaf anatomical adaptations in some exotic species of Eucalyptus 1'her. (Myrtaceae). Pak J of Bot 41 (6): 2717-2727.

Anjum SA, Xie X, Wang L, Saleem MF, Man C, Lei W. 2011. Morphological, physiological and biochemical responses of plants to drought stress. Afr J Agric Res 6 (9): 2026-2032.

Custódio DL, Kolb RM, Faria TJ, Bianchini E. 2013. Pimenta pseudocaryophyllus (Gomes) L.R. Landrum (Myrtaceae): stem and leaf anatomy of a medicinal plant. Semina: Ciênc Biol Saúde, Londrina. 34 (2): 111-124.

El-Domyati FME, Ramadan AM, Gadalla NO, Edris S, Shokry AM, Hassan SM, Hassanien SE, Baeshen MN, Hajrah NH, Al-Kordy MA Abuzinadah QA, Al-Hajar ASM, Akoh CC, Bahieldi A. 2012. Identification of molecular markers for flower characteristics in Catharanthus roseus producing anticancer compounds. Life Sci J 9 (4): 5949-5960

Gloria RY, Iswari RS. 2015. Analysis of chlorophyll content in six traditional medicinal plants as an alternative food supplement. Proceedings of the IconSSE FSM SWCU. Universitas Kristen Satya Wacana, Salatiga.

Hameed M, Ashraf M, Naz N, Nawaz T, Batool R, Ahmad MSA, Ahmad F, Hussain M. 2013. Anatomical adaptations of Cynodon dactylon (1.) Pers. From the salt range (Pakistan) to salinity stress. II. Leaf anatomy. Pak J Bot 45 (S1): 133-142

Haryanti S. 2010. Effect of different shade on stomata amount and stomata porus size Zephyranthes rosea Lindl leaves. Buletin Anatomi dan Fisiologi 18 (1): 41-48. [Indonesian]

Hasidah, Mukarlina, Rousdy DW. 2017. Kandungan pigmen klorofil, karotenoid dan antosianin daun Caladium. J Protobiont 6 (2): 29-37 [Indonesian]

Jaleel CA, Gopi R, Manivannan P, Panneerselvam. 2008. Soil salinity alters the morphology in Catharanthus roseus and its effects on endogenous mineral constituents. Eur Asian J BioSci 2: 18-25.

Jingura RM, Kamusoko R. 2015. Utility of markers for determination of genetic diversity in Jatropha: A Review. Open Renew Energy J 8: 1-6

Kumar V, Singh PK, Dudhane AS, De DK, Satya P. 2014. Anatomica and morphological characteristics of nine jute genotypes. J Crop Weed 10 (2): 334-339

Maghsoudi K, Maghsoudi moud A. 2008. Analysis of the effects of stomatal frequency and size on transpiration and yield of whea (Triticum aestivum L.). Am Eurasian J Agric Environ Sci 3 (6): 865872
Masungsong LA, Belarmino MM, Buot JR IE. 2019. Delineation of the selected Cucumis L. species and accessions using leaf architecture characters. Biodiversitas 20 (3): 629-635

Mlodzinska E. 2009. Survey of plant pigments: molecular and environmental determinants of plant colors. Acta Biol Gracoviensia Ser Bot 51 (1): 7-16

Nejat N, Maziah M, Valdiani A, Tan YH, Cahill D, Abiri R. 2015. Ornamental exterior versus therapeutic interior of Madagascar periwinkle (Catharanthus roseus): the two faces of a versatile herb. Review Article. Sci World J. 2015: ID 982412. DOI: $10.1155 / 2015 / 982412$

Pandiangan D. 2012. The morphological and anatomical changes on tryptophan-treated callus of Catharanthus roseus. J Biologos 2 (1): 45-49.

Pantilu LI, Mantiri FR, Ai NS, Pandiangan D. 2012. Morphological and anatomical responses of the soybean (Glycine max L.) Merill) sprouts to the different light intensity. J Biol 2 (2): 80-87.

Pitoyo A, Prameta AA, Marsusi, Suratman, Suranto. 2018. Morphological, anatomical and isozyme variability among taro (Colocasia esculenta) accessions from southeastern part of Central Java, Indonesia. Biodiversitas 19 (5): 1811-1819.

Plaizier AC. 1981. A revision of Catharanthus roseus (L.) G. Don (Apocynaceae). Meded Landbouwhogeschool 81 (9): 1-12.

Renoult J, Nuzillard J, Mare L, Le Crouerour G, Thepeiner P, Harnot Z. 1999. Isolation of indol alkaloids from $C$. roseus by centrifuged partition chromatography in the $\mathrm{pH}$ zone refining mode. J Chromatog A 849 (2): 421-431

Saadu RO, Abdulrahman AA, Oladele FA. 2009. Stomatal complex dan transpiration rates in some tropical tuber species. African J Plant Sci 3 (5): 107-112

Salisbury FB, Ross CW. 1995. Fisiologi Tumbuhan Jilid 1 Edisi 4. ITB Press, Bandung. [Indonesian]

Samiyarsih S, Juwarno J, Muljowati JS. 2018. The structural resistance's anatomy of sweet potato leaves to fungal pathogen Sphaceloma batatas. Biosaintifika 10 (1): 131-137.

Shaw RK, Acharya L, Mukherjee AK. 2009. Assessment of genetic diversity in a highly valuable medicinal plant Catharanthus roseus using molecular markers. Crop Breed Appl Biotech 9: 52-59.

Taiz L, Zieger E. 1998. Plant Physiology. $3^{\text {rd }}$ ed. Sinauer Associates, Sunderland.

Tanzerina N, Juswardi, Elyza F. 2013. Adaptation study of anatomy of vegetative organs Neptunia oleraceae lour results of selection of line in phytoremediation of ammonia liquid waste. Prosiding Semirata FMIPA Universitas Lampung, Bandar Lampung. [Indonesian]

Zen AR, Widoretno W, Indriyani S. 2016. Water and chlorophyll content and leaf anatomy of patchouli planlet (Pogostemon cablin Benth.) resulted by shoot-tip culture experience hyperhydricity after treatment of modification ammonium nitrate or macro salt concentration on MS medium (Murashige Skoog). J Exp Life Sci 6 (1): 38-44. 